\title{
Retraction: Soft braces in the treatment of Adolescent Idiopathic Scoliosis (AIS) - Review of the literature and description of a new approach
}

\author{
Hans-Rudolf Weiss ${ }^{1 *}$ and Mario Werkmann ${ }^{2}$
}

The Editor-in-Chief and the Medical Editors at BioMed Central have retracted this article [1] because the first author did not fully declare his association with Koob Scolitech, which holds the rights in and to the Spinealite $^{\mathrm{TM}}$ brace and has filed for a patent for that brace. Furthermore, the direct association between Koob Scolitech and the Spinealite ${ }^{\mathrm{TM}}$ brace was not made clear in the article. This undeclared competing interest compromised the peer review process.

\section{Author details}

${ }^{1}$ Orthopedic Rehabilitation Services, Alzeyerstr, 23, Gensingen D-55457,

Germany. ${ }^{2}$ Orthomed Scolicare, Orthopedic Technical Services, Alzeyerstr, 23, Gensingen D-55457, Germany.

Received: 22 March 2013 Accepted: 26 March 2013

Published: 3 May 2013

\section{Reference}

1. Weiss HR, Werkmann M: Soft braces in the treatment of Adolescent Idiopathic Scoliosis (AIS) - Review of the literature and description of a new approach. Scoliosis 2012, 7:11.

\footnotetext{
* Correspondence: hr.weiss@skoliose-dr-weiss.com

'Orthopedic Rehabilitation Services, Alzeyerstr, 23, Gensingen D-55457,

Germany

Full list of author information is available at the end of the article
}

Submit your next manuscript to BioMed Central and take full advantage of:

- Convenient online submission

- Thorough peer review

- No space constraints or color figure charges

- Immediate publication on acceptance

- Inclusion in PubMed, CAS, Scopus and Google Scholar

- Research which is freely available for redistribution 